\title{
STUDI LITERATUR : PENCEGAHAN PENYEBARAN SARS-CoV-2 PADA PRAKTIK KEDOKTERAN GIGI
}

\author{
Ira Liasari, Hans Lesmana
}

\begin{abstract}
ABSTRAK
Pandemi COVID-19 sangat berdampak pada praktik kedokteran gigi. Dokter gigi dan tim harus waspada karena tingginya resiko penularan dan penyebaran SARS-Cov-2. Hal ini disebabkan karena adanya kemungkinan terhirup aerosol atau droplet yang mengandung virus. atau kontak langsung dengan membran mukosa, cairan mulut, dan instrumen dan permukaan yang terkontaminasi virus selama tindakan kedokteran gigi di klinik. Tujuan dari studi literatur ini untuk mengetahui upaya-upaya yang dapat dilakukan untuk mencegah penularan dan penyebaran COVID-19 di praktik kedokteran gigi. Studi literatur ini diperoleh dari penelusuran artikel penelitian penelitian ilmiah dari rentang tahun 2019-2020 melalui website WHO, PubMeds, ScienceDirect, The Lancet, Springer Nature, dan Elsevier. Dari berbagai literatur didapatkan bahwa pencegahan dapat dilakukan melalui manajemen pasien dan pencegahan infeksi nasokomial sebelum perawatan gigi, penggunaan alat pelindung diri bagi dokter gigi dan tim, tindakan pencegahan selama perawatan gigi, disinfeksi klinik, dan manajemen limbah medis.
\end{abstract}

Kata Kunci: COVID-19, Dokter Gigi, Perawat Gigi, SARS-CoV-2

\section{PENDAHULUAN}

Pada bulan Desember 2019, virus corona tipe baru yang dapat menyebabkan pneumonia ditemukan pertama kali di Wuhan, China.(Li et al., 2020) Virus ini semula disebut sebagai 2019 novel coronavirus (2019-nCoV), kemudian secara resmi dinamakan menjadi severe acute respiratory syndrome coronavirus 2 (SARS-CoV-2) oleh the International Committee on Taxonomy of Viruses (ICTV) pada tanggal 11 Februari 2020. Di hari yang sama WHO lalu mengumumkan "COVID-19" sebagai nama penyakit yang disebabkan oleh virus tersebut. (WHO, 2020b)

Coronavirus disease 2019 (COVID-19) menyebar dengan cepat ke berbagai negara dan pada tanggal 11 Maret 2020 WHO mengumumkan COVID-19 sebagai pandemi. (WHO, 2020a). Di Indonesia, kasus Covid-19 pertama kali diumumkan pada tanggal 2 Maret 2020 dan hingga saat draft ini diturunkan sudah mencapai 64.958 kasus terkonfirmasi dan 3.241 (4,99\%) meninggal dunia.(Kemenkes RI, 2020)

Pandemi COVID-19 ini berpengaruh sangat besar terhadap berbagai profesi kesehatan, termasuk diantaranya profesi dokter gigi, dan perawat gigi atau terapis gigi dan mulut. Profesi dokter gigi dan perawat gigi atau terapis gigi dan mulut merupakan profesi yang rentan terjadi infeksi silang beberapa penyakit menular karena sering terpapar dengan saliva dan darah. (Laheij et al., 2012). SARS-CoV-2, virus yang menyebabkan COVID-19 ini juga memungkinkan terjadinya penularan di praktik kedokteran gigi karena adanya kemungkinan terhirup aerosol atau droplet yang mengandung virus.atau kontak langsung dengan membran mukosa, cairan mulut, dan instrumen dan permukaan yang terkontaminasi virus.(Chen et al., 2020)

Studi literatur ini bertujuan untuk mengidentifikasi upaya-upaya yang dapat dilakukan untuk pencegahan penyebaran dan penularan COVID-19 pada praktik kedokteran gigi selama masa pandemi.

\section{METODE}

Metode yang digunakan dalam penulisan ini adalah studi literatur. Sumber pustaka yang digunakan dalam penyusunan artikel melalui website WHO, PubMeds, ScienceDirect, The Lancet, Springer Nature, dan Elsevier. Pencarian artikel dengan melakukan pengumpulan tema COVID 19, SARS-CoV-2 yang dikaitkan dengan praktek kedokteran gigi. Pembatasan proses pencarian tidak hanya dikaitkan dengan tema, namun juga tahun 
diterbitkannya artikel tersebut. Tahun penerbitan artikel yang di pakai adalah tahun 2019-2020. Adapun kata kunci pencarian yaitu COVID-19, SARS-CoV-2 dan dentist.

\section{HASIL DAN PEMBAHASAN}

Tindakan kedokteran gigi dapat menimbulkan terjadinya aerosol dari saliva ataupun darah dari pasien, terutama pada saat penggunaan ultrasonic scaler, high speed handpiece dan three way syringe. Aerosol yang dihasilkan dan berbagai macam mikroorganisme yang terkandung di dalam aerosol dapat terhirup dan masuk ke dalam saluran pernafasan pasien maupun dokter gigi dan tim (Vanishree et al., 2012). Pada kasus pasien positif COVID-19, apabila dilakukan tindakan keperawatan gigi , terutama scaling dengan ultrasonic scaler dapat menyebabkan saliva yang mengandung virus teraerosol dan menyebar serta mengkontaminasi dental unit. SARS-CoV-2 ini dapat bertahan sampai 3 jam di aerosol dan dapat terdeteksi di permukaan benda-benda sampai 72 jam. Hal ini menyebabkan tingginya resiko perawat gigi terpapar SARS-CoV-2 (Passarelli et al., 2020). Penyebaran SARS-CoV-2 ini tidak hanya terjadi jika pasien sudah memiliki gejala COVID-19, namun jika pasien adalah orang tanpa gejala (OTG), penyebaran virus ini juga dapat terjadi (Chang et al., 2020) . Berdasarkan beberapa referensi yang dapat dilakukan di antaranya adalah manajemen pasien dan pencegahan infeksi nasokomial sebelum perawatan gigi, penggunaan alat pelindung diri bagi dokter gigi dan tim, tindakan pencegahan selama perawatan gigi, dan sanitasi lingkungan. (Ather, Biraj Patel, et al., 2020; Passarelli et al., 2020; Peditto et al., 2020)

\author{
Manajemen Pasien dan Pencegahan Infeksi \\ Nosokomial \\ Pada masa pandemik COVID-19, perlu
}

dilakukan manajemen pasien dan melakukan tindakan-tindakan yang dapat mencegah terjadinya infeksi nosokomial. Pasien yang datang ke klinik perlu dibatasi untuk menghindari penyebaran virus antar pasien (Lai et al., 2020). Pembatasan jumlah pasien yang datang ke klinik dapat dilakukan dengan cara telescreening dan triage.

Screening pasien melalui telepon atau media komunikasi lainnya perlu dilakukan agar pasien dapat dikelompokkan. Screening pada pasien ini disarankan oleh beberapa artikel jurnal di antaranya oleh Ather, Biraj Patel, et al., (2020); Ge et al., (2020); Lai et al., (2020), juga oleh American Dental Association (2020). Screening jarak jauh atau telescreening dapat berupa kuesioner berisi pertanyaan yang diajukan kepada pasien, diantaranya pertanyaan mengenai pernah tidaknya berkontak dengan orang lain yang merupakan suspek COVID-19, pernah melakukan perjalanan ke daerah dengan angka insiden COVID-19 yang tinggi, atau ada atau tidaknya gejala demam dan batuk (Ather, Bira Patel, et al., 2020; Ge et al., 2020; Lai et al., 2020). Screening dan triage digambarkan dalam bagan 1 .

Demikian juga di ruang tunggu klinik, perlu diatur sedemikian rupa agar terdapat jarak antar pasien minimal 1 meter (Chu et al., 2020; Rahman and Bahar, 2020). Ruang tunggu harus difasilitasi dengan hand sanitizer. Pasien diperiksa suhu tubuhnya dan diwajibkan memakai masker bedah. Pemakaian masker bedah ini sesuai dengan standar alat pelindung diri level 1 menurut klasifikasi American Society for Testing and Materials (ASTM). (ASTM Standards \& COVID-19, no date) Masker bedah dapat menahan $97,14 \%$ virus dari aerosol. (Ma et al., 2020) 


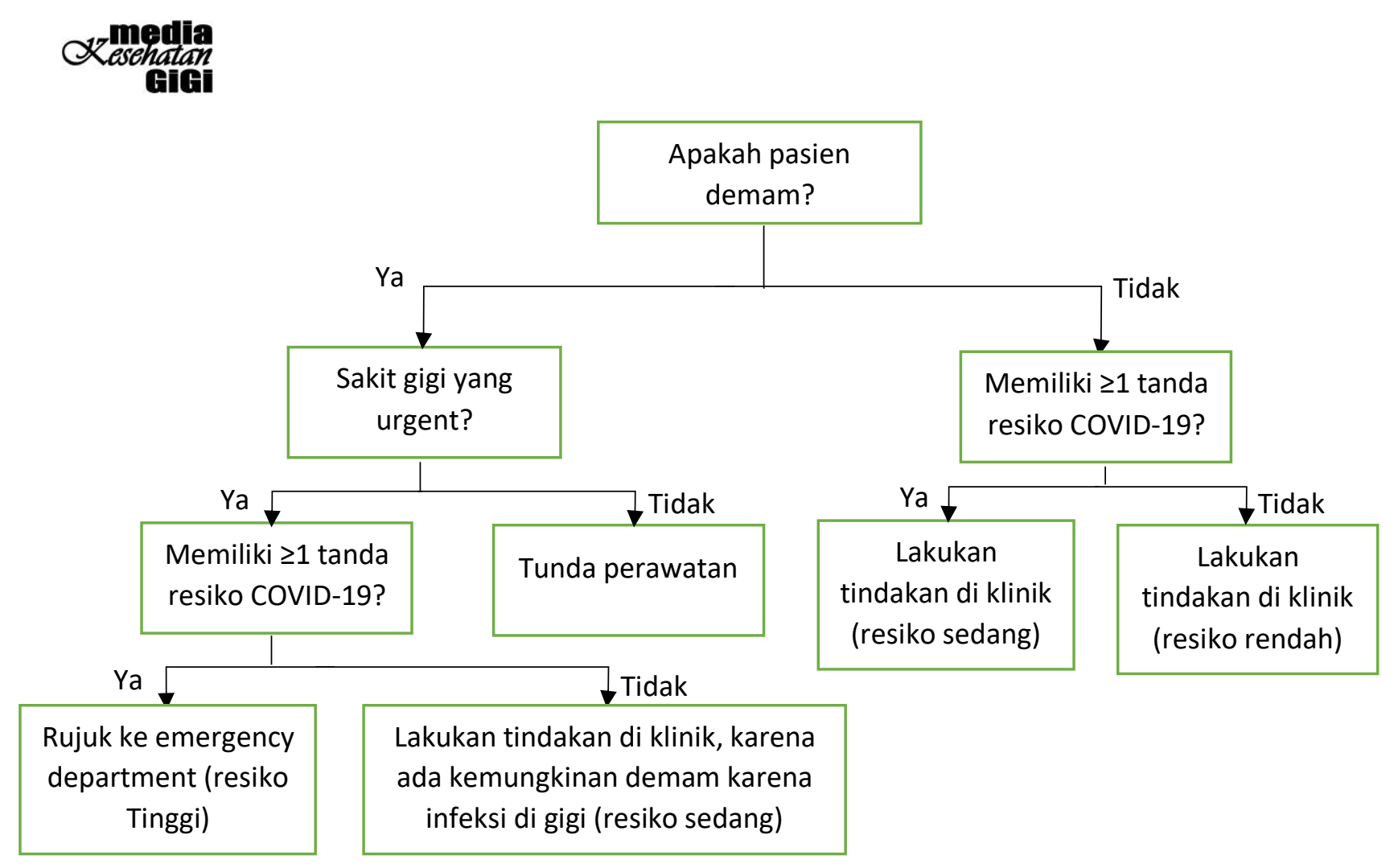

Bagan 1. Telescreening dan Triage. Sumber: The impact of the COVID-19 infection in dentistry (3)

\section{Langkah-langkah Pencegahan}

Pada masa pandemi COVID-19 seperti saat ini, menggunakan alat pelindung diri (APD) dan prosedur yang konvensional saja tidak cukup dalam mencegah penularan dan penyebaran. Untuk itu dokter gigi dan timnya harus memperhatikan APD dan prosedur serta alat apa saja yang dapat mengurangi resiko penyebaran COVID-19.

\section{Alat Pelindung Diri (APD)}

California Dental Association (CDC) merekomendasikan penggunaan APD level 3 yang terdiri dari masker N95/KN95, face shield, gown, sarung tangan, penutup kepala, dan penutup sepatu, jika dokter gigi akan melakukan tindakan yang akan menimbulkan aerosol. (Back to Office, Preparing Your Practice, 2020) Menurut Peng dkk. terdapat 3 level alat pelindung diri yang dapat digunakan pada praktik kedokteran gigi. Level pertama, yaitu proteksi standar untuk staf klinik menggunakan penutup kepala sekali pakai, masker bedah sekali pakai, jas putih, goggle atau face shield, dan sarung tangan lateks atau nitrile sekali pakai. Level 2, yaitu untuk proteksi dokter menggunakan alat pelindung diri seperti pada level 1 ditambah dengan jubah/pakaian bedah sekali pakai. Sedangkan level 3 digunakan untuk melakukan tindakan pada pasien dengan suspek atau terkonfirmasi COVID-19. APD level 3 yang digunakan yaitu penggunaan pakaian proteksi (hazmat). Jika hazmat tidak tersedia, maka dapat menggunakan jas putih dengan dilapisi gown atau jubah sekali pakai, serta ditambah dengan goggle atau face shield, sarung tangan lateks sekali pakai dan penutup sepatu.(Peng et al., 2020)

\section{Berkumur dengan Obat Kumur Antiseptik}

Pada umumnya dokter gigi meminta pasien berkumur sebelum dilakukan tindakan perawatan gigi. Namun penggunaan Clorhexidine sebagai obat kumur, tidak efektif membunuh SARS-CoV-2(Peng et al., 2020). Hydrogen peroxide $1 \%$ atau povidone $0.2 \%$ direkomendasikan untuk mengurangi mikroba yang terdapat pada saliva, termasuk SARS-CoV2(Ather, Biraj Patel, et al., 2020; Peng et al., 2020). Namun demikian karena tingginya kandungan virus dalam saliva, obat kumur hanya mampu mengurangi namun tidak dapat menghilangkan virus. (Meng, Hua and Bian, 2020; Peng et al., 2020)

\section{Rubber Dam dan High Volume Evacuator}

Pada perawatan gigi, sulit untuk menghindari terbentuknya aerosol. Oleh sebab itu 
selain menggunakan obat kumur untuk mengurangi kandungan virus di saliva, maka dokter gigi dan tim dapat juga menggunakan rubber dam dan high volume evacuator untuk mengurangi kontaminasi aerosol.

Penggunaan rubber dam pada tindakan konservasi gigi dapat mengurangi kontaminasi terhadap saliva dan darah. Penggunaan rubber dam dapat mengurangi partikel airborne sampai dengan 98,8\% (El-Din and Ghoname, 1997). Namun penggunaan rubber dam sangat terbatas, tidak dapat digunakan pada tindakan restorasi sub gingival, preparasi tahap akhir pembuatan crown, dan pada perawatan periodontal seperti root planing, bedah periodontal, atau scalling menggunakan ultrasonic scaller.

Pengurangan kontaminasi mikroorganisme dari aerosol yang dihasilkan pada saat menggunakan high speed handpiece, air syringe, dan ultrasonic scaler dapat dilakukan dengan menggunakan high volume evacuator (HVE). HVE adalah suction yang dapat menghisap udara sampai dengan 2,83 $\mathrm{m}^{3}$ per menit. Dengan menggunakan HPE, aerosol dapat terhisap sehingga kontaminasi dapat berkurang sampai $90 \%$. Tetapi ketika menggunakan HPE ini dokter harus dibantu oleh asisten atau perawat gigi (Narayana et al., 2016; Ge et al., 2020).

\section{Disinfeksi Klinik}

Pada masa pandemi COVID-19, disinfeksi ruang klinik dan ruang publik harus dilakukan lebih ketat. Pembersihan dan disinfeksi harus dilakukan dengan mengikuti protokol pembersihan dan disinfeksi yang ada (Peng et al., 2020). Instrumen yang dapat dipakai ulang harus dibersihkan, disinfeksi, sterilisasi dan disimpan sesuai dengan protokol. Semua permukaan peralatan, misalnya kursi, gagang pintu, komputer, dan permukaan benda lainnya harus didisinfeksi. Untuk permukaan yang tidak mudah berkarat dapat dilap menggunakan larutan klorin 500mg/L-1000 mg/L. Sedangkan permukaan benda yang mudah berkarat dapat menggunakan ethanol 75\%. Permukaan benda yang frekuensi kontaknya sangat tinggi seperti wastafe, keran, dan gagang pintu harus didisinfeksi minimal 2 jam sekali.(Shanshan and Shuguo, 2020) Di Italy,untuk disinfeksi permukaan benda disarankan menggunakan $0.1 \%$ sodium hypochlorite dan $70 \%$ isopropyl alcohol.(Izzetti et al., 2020). Lebih lengkap lagi, Peditto dkk., (2020) menyarankan penggunaan $70 \%$ ethyl alcohol, Potassium peroxymonosulphate solution (1/100 dilution), $2.5 \%$ sodium hypochlorite, dan $55 \%$ hydroalcoholic solution dengan quaternary ammonium propionate, dengan cara diaplikasikan pada permukaan benda dengan kertas tisu sekali pakai selama 5 menit.

Menurut Cheong \& Phua (2006) sebagaimana dikutip dalam Volgenant et al. (2020). Bekerja dalam ruangan bertekanan negatif dapat menjadi pilihan. Namun tidak semua klinik dapat menggunakan ruangan bertekanan negatif, sehingga cukup dengan ventilasi yang memadai (Meng, Hua and Bian, 2020) atau membuka jendela untuk ventilasi udara selama melakukan tindakan perawatan gigi. Setelah selesai shift pagi dan shift malam ruangan dapat dilakukan disinfeksi dengan lampu ultraviolet selama 30-60 menit, kemudian jendela dibuka untuk ventilasi selama minimal 30 menit.(Shanshan and Shuguo, 2020)

Laintai klinik harus sering dibersihkan, dikeringkan, dan didisinfeksi setiap 2 jam. Cairan yang dianjurkan untuk digunakan adalah larutan klorin $500 \mathrm{mg} / \mathrm{L}-1000 \mathrm{mg} / \mathrm{L}$. Semua alas lantai seperti karpet atau keset harus dilepaskan. Setelah selesai shift lantai dipel dengan larutan klorin 1000 $\mathrm{mg} / \mathrm{L}$ sebelum ruangan didisinfeksi dengan ultraviolet.(Shanshan and Shuguo, 2020)

\section{Manajemen Limbah Medis}

Limbah medis, termasuk APD sekali pakai misalnya masker bedah, penutup kepala, dan sebagainya harus diletakkan pada tempat penyimpanan sementara sebelum dibuang. Pembuangan limbah medis harus dilakukan setiap hari. Setelah limbah medis dibuang, tempat penyimpanan limbah medis sementara harus didisinfeksi dengan larutan klorin 1000mg/L. Pembuangan limbah medis ini harus dilakukan oleh 
staf yang sudah dilatih, dan staf tersebut harus menggunakan APD pada saat melakukukan proses pembuangan limbah dan pembersihan tempat penyimpanan sementara. (Shanshan and Shuguo, 2020)

\section{KESIMPULAN}

Berbagai upaya perlu dilakukan untuk mencegah penularan COVID-19 di tempat praktik kedokteran gigi. Dari berbagai literatur didapatkan bahwa pencegahan dapat dilakukan melalui manajemen pasien dan pencegahan infeksi nasokomial sebelum perawatan gigi, penggunaan alat pelindung diri bagi dokter gigi dan tim, tindakan pencegahan selama perawatan gigi, disinfeksi klinik, dan manajemen limbah medis.

\section{Daftar Pustaka}

American Dental Association, A. (2020) Summary of ADA Guidance During the COVID-19 Crisis. Available at: https://success.ada.org/ /media/CPS/Files/ COVID/ (Accessed: 6 July 2020).

ASTM Standards \& COVID-19 (no date). Available at: https://www.astm.org/COVID-19/ (Accessed: 25 June 2020).

Ather, A., Patel, Biraj, et al. (2020) 'Coronavirus Disease 19 (COVID-19): Implications for Clinical Dental Care', Journal of Endodontics. Elsevier Inc., pp. 584-595. doi: 10.1016/j.joen.2020.03.008.

Ather, A., Patel, Bira, et al. (2020) 'Coronavirus Disease 19 (COVID-19): Implicationsfor Clinical Dental Care', JOE, 45(January), pp. 584-595.

Back to Office, Preparing Your Practice (2020). Available at: https://www.cda.org/Portals/0/EasyDNNne ws/Uploads/1927/Preparing your practice PPE - PPE Recommendations for Dental Practices final1.pdf (Accessed: 27 June 2020)

Chang, D. et al. (2020) 'Protecting health-care workers from subclinical coronavirus infection', The Lancet Respiratory Medicine. Lancet Publishing Group, p. e13. doi: 10.1016/S2213-2600(20)30066-7.

Chen, N. et al. (2020) 'Epidemiological and clinical characteristics of 99 cases of 2019 novel coronavirus pneumonia in Wuhan, China: a descriptive study', www.thelancet.com, 395 , p. 507. doi: 10.1016/S01406736(20)30211-7.

Chu, D. K. et al. (2020) 'Physical distancing, face masks, and eye protection to prevent person-to-person transmission of SARSCoV-2 and COVID-19: a systematic review and meta-analysis', The Lancet, 6736(20), pp. 1-15. doi: 10.1016/s0140-
6736(20)31142-9.

El-Din, A. M. T. and Ghoname, N. A. E. H. (1997) 'Efficacy of rubber dam isolation as an infection control procedure in paediatric dentistry', Eastern Mediterranean Health Journal, 3(3), pp. 530-539.

Ge, Z.-Y. et al. (2020) 'Possible aerosol transmission of COVID-19 and special precautions in dentistry *', J Zhejiang Univ-Sci B (Biomed \& Biotechnol) 2020, 21(5), pp. 361-368. doi: $10.1631 /$ jzus.B2010010.

Izzetti, R. et al. (2020) 'COVID-19 Transmission in Dental Practice: Brief Review of Preventive Measures in Italy', Journal of Dental Research, 00(0), pp. 1-9. doi: $10.1177 / 0022034520920580$.

Kemenkes RI (2020) Kementerian Kesehatan Republik Indonesia. Available at: https://www.kemkes.go.id/article/view/2003 1900002/Dashboard-Data-Kasus-COVID19-di-Indonesia.html (Accessed: 6 July 2020).

Laheij, A. M. G. A. et al. (2012) 'Healthcareassociated viral and bacterial infections in dentistry', Journal of Oral Microbiology, 4, pp. $1-10$.

Lai, T. H. T. et al. (2020) 'Stepping up infection control measures in ophthalmology during the novel coronavirus outbreak: an experience from Hong Kong', Graefe's Archive for Clinical and Experimental Ophthalmology. Graefe's Archive for Clinical and Experimental Ophthalmology, 258(5), pp. 1049-1055. doi: 10.1007/s00417-020-04641-8.

Li, W. et al. (2020) 'Protocol for the development of a rapid advice guideline for prevention, management and care of children with 2019 novel coronavirus infection', Annals of palliative medicine. NLM (Medline), $0(0)$. doi: 10.21037/apm.2020.02.33.

$\mathrm{Ma}, \mathrm{Q}$. X. et al. (2020) 'Potential utilities of maskwearing and instant hand hygiene for fighting SARS-CoV-2', Journal of Medical Virology, (March). doi: 10.1002/jmv.25805.

Meng, L., Hua, F. and Bian, Z. (2020) 'Coronavirus Disease 2019 ( COVID-19 ): Emerging and Future Challenges for Dental and Oral Medicine', Journal of Dental Research, 99(5), pp. 481-487. doi: $10.1177 / 0022034520914246$.

Narayana, T. et al. (2016) 'Role of preprocedural rinse and high volume evacuator in reducing bacterial contamination in bioaerosols', Journal of Oral and Maxillofacial Pathology, 20(1), pp. 59-65. doi: 10.4103/0973-029X.180931.

Passarelli, P. C. et al. (2020) 'The impact of the COVID-19 infection in dentistry', Experimental Biology and Medicine, 0, pp. 1-5. doi: $10.1177 / 1535370220928905$.

Peditto, M. et al. (2020) 'Dentistry during the COVID19 Epidemic: An Italian Workflow for the Management of Dental Practice', International Journal of Environmental Research and Public Health, 17(February), pp. 1-15. 
Peng, X. et al. (2020) 'Transmission routes of 2019nCoV and controls in dental practice', International Journal of Oral Science. Springer Nature, pp. 1-6. doi: 10.1038/s41368-020-0075-9.

Rahman, S. and Bahar, T. (2020) 'COVID-19: The New Threat', International Journal of Infection, 7(1), pp. 1-6. doi: 10.5812/iji.102184

Shanshan, Z. and Shuguo, Z. (2020) COVID-19 and dental practice. What has been done in China? Beijing. Available at: https://www.fdiworlddental.org/sites/default /files/media/documents/covid-

19_and_dental_practice_what_has_been done in china.pdf.

Vanishree, N. et al. (2012) 'Aerosol: A Silent Killer In Dental Practice', Annal and Essences of Dentistry Journal, IV(3), pp. 55-59.
Volgenant, C. M. C. et al. (2020) 'Infection control in dental health care during and after the SARS-CoV-2 outbreak', Oral Diseases. Blackwell Publishing Ltd. doi: 10.1111/odi.13408.

WHO (2020a) Archived: WHO Timeline - COVID-19. Available at: https://www.who.int/newsroom/detail/27-04-2020-who-timeline--covid-19 (Accessed: 6 July 2020).

WHO (2020b) Naming the coronavirus disease (COVID-19) and the virus that causes it. Available

at: https://www.who.int/emergencies/diseases/ novel-coronavirus-2019/technical-

guidance/naming-the-coronavirus-disease(covid-2019)-and-the-virus-that-causes-it (Accessed: 6 July 2020). 